\title{
Významné recentní publikace v intervenční kardiologii a príbuzných oborech
}

\author{
Josef Veselka \\ Kardiologické oddělení Kardiovaskulárního centra, Fakultní nemocnice v Motole, Praha, Česká republika
}

\begin{abstract}
Adresa: prof. MUDr. Josef Veselka, CSc., FESC, FSCAI, FICA, Kardiologické oddělení Kardiovaskulárního centra, FN v Motole, V úvalu 84, 15000 Praha 5, Česká republika, e-mail:Veselka.josef@seznam.cz
\end{abstract}

Je obvyklé stanovovat za určité období nejlepší sportovce, nejlepší vědce, publikace. Je to sice obvyklé, vždy však velmi subjektivní, a tudíž nepřesné. Prosím tedy čtenáře, aby se shovívavostí četli následující řádky, ve kterých jsem se pokusil připomenout některé významné publikace posledních měsíců, a to především ty, o nichž jsem přesvědčen, že by měly ovlivňovat naši medicínskou praxi.

Většina koronárních intervencí je stále vedena na základě angiografií, ačkoli je dobře známo, že angiografie je ve srovnání s intravaskulárním ultrazvukem velmi nepřesná, a to především při hodnocení stenóz v rozmezí 40-80\%. Totéž platí i při hodnocení funkčních důsledků významných stenóz. Frakční průtoková rezerva (FFR) se v experimentu i klinické praxi osvědčila jako nejpřesnější způsob měření funkční významnosti koronárních stenóz. V této souvislosti randomizovaná multicentrická studie FAME (The Fractional Flow Reserve versus Angiography for Guiding PCI in Patients with Multivessel Coronary Artery Disease) ukázala, že pacienti s chorobou více tepen léčení pomocí koronární intervence, vedené na základě výsledků FFR vyšetření, mají při jednoročním sledování signifikantně menší výskyt infarktů myokardu nebo úmrtí ve srovnání $s$ nemocnými ošetřenými pomocí intervence vedené standardně prováděnou angiografií $(7,3 \%$ vs. $11,1 \%, p=0,04){ }^{(1)}$ Pozitivně pro FFR vedené intervence vyšel i primární sledovaný ukazatel, kterým byl jednoroční výskyt úmrtí, infarktu myokardu nebo opakované revaskularizace (13,2\% vs. $18,3 \%, p=0,02)$. Zajímavým faktem byla i nižší spotřeba stentů a kontrastních látek ve skupině FFR. Tato studie tedy potvrdila známý fakt, že především u nemocných s komplexním koronárním nálezem je výhodné nespoléhat se př̀ hodnocení nálezu a vedení intervence pouze na angiografii.

Při rozhodování o správné terapii nemocných s komplexním koronárním postižením více věnčitých tepen po- citovali intervenční kardiologové dosud velkou nejistotu, pokud jde o použití více lékových stentů při ošetření jednoho nemocného. Studie SYNTAX je první randomizovaná multicentrická studie, srovnávající účinnost a bezpečnost implantace paclitaxelových stentů (Taxus) ve srovnání s chirurgickou revaskularizací u nemocných s postižením více tepen a/nebo stenózou kmene levé věnčité tepny. ${ }^{(2)}$ Zařazeno bylo 1800 nemocných; kompozitní výsledný sledovaný ukazatel zahrnující úmrtí, infarkt myokardu, cévní mozkovou př́hodu a opakovanou revaskularizaci byl ve 12 měsíčním sledování významně častější ve skupině léčené stenty $(17,8 \%$ vs. $12,1 \%, p=0,0015)$ vzhledem $\mathrm{k}$ častějším opakovaným revaskularizacím u katetrizačně léčené skupiny. Nebyl významný rozdíl ve výskytu úmrtí, cévní mozkové prríhody nebo infarktu myokardu (7,6 \% vs. $7,7 \%, p=0,98)$. Výskyt cévní mozkové příhody byl signifikantně častější u nemocných po chirurgické revaskularizaci $(2,2 \%$ vs. $0,6 \%, p=0,003)$. Tyto výsledky je nutno chápat v kontextu zahrnutí pacientů s komplexně postiženými věnčitými tepnami. Proto bylo nezbytné implantovat v průměru $86 \mathrm{~mm}$ (!) stenty do věnčitých tepen u jednoho pacienta a u třetiny nemocných dokonce více než $100 \mathrm{~mm}$ stenty. Výsledky katetrizační léčby je tedy možno hodnotit z hlediska bezpečnosti i účinnosti jako uspokojivé. Celá problematika má i nadále mnoho nevyřešených otázek, z nichž těmi nejdůležitějšími jsou výsledky skutečně dlouhodobé (po 3-10 letech) a rovněž výsledky jednotlivých podskupin pacientů. V současné době je i nadále správným postupem pro většinu těchto pacientů chirurgická revaskularizace.

Léčba nemocných se stabilní anginou pectoris se stala předmětem velkých diskusí především po publikaci výsledků studie COURAGE (Clinical Outcomes Utilizing Revascularization and Aggressive Drug Evaluation). ${ }^{(3)}$ Ta prokázala, že u pacientů se stabilní anginou pectoris není při 
srovnání optimální farmakoterapie a perkutánní koronární intervence (PCI) v dlouhodobém sledování rozdíl ve výskytu úmrtí nebo infarktu myokardu. Identická studie byla postupně podrobena dalším analýzám a $\mathrm{v}$ jedné $\mathrm{z}$ nich, publikované v loňském roce, prokázali Weintraub a spol., ${ }^{(4)}$ že nemocní léčení PCI vykazovali tři roky po výkonu signifikantně vyšší kvalitu života $\mathrm{v}$ řadě sledovaných parametrů. Po třech letech již byly rozdíly mezi oběma skupinami pacientů nesignifikantní. I nadále si přívrženci obou zmiňovaných postupů mohou tedy nacházet dobré důvody, proč je používat, nicméně PCI (aspoň v té podobě, jak se prováděla v USA a Kanadě v období 1999-2004) přinejmenším zlepšuje na přechodnou dobu kvalitu života u stabilních nemocných s ischemickou chorobou srdeční (ICHS).

Dlouhá léta se vedly spory o optimální léčbu akutního infarktu myokardu s elevací segmentu ST (STEMI). Poté, co katetrizační terapie jednoznačně prokázala svou bezpečnost i velkou účinnost, došlo na možnosti „facilitované“ PCI u těchto pacientů. Celý koncept je jednoduchý a představuje snahu o rychlou reperfuzi na úrovni velkých epikardiálních tepen pomocí PCI i mikrocirkulace kombinací trombolytické a antitrombotické terapie. Studie FINESSE (Facilitated Intervention with Enhanced Reperfusion Speed to Stop Events $)^{(5)}$ však celou tuto koncepci značně oslabila. V této studii bylo randomizováno 2452 pacientů se STEMI do šesti hodin od začátku obtíží; byli rozděleni do skupin léčených primární PCI, primární PCI s podáním abciximabu a primární PCI s podáním kombinace abciximabu a poloviční dávky reteplázy. V̌̌ichni pacienti byli současně léčeni enoxaparinem nebo nefrakcionovaným heparinem. Primární výsledný ukazatel (úmrtí, komorová fibrilace vzniklá po 48 hodinách od začátku infarktu, kardiogenní šok a srdeční selhání do 90 dnů od vzniku infarktu) byl téměř identický u všech tř́i skupin pacientů (9,8 \% vs. 10,5 \% vs. 10,7 \%, NS). Zcela nevýznamné rozdíly byly i při sledování tř́měsíční mortality $(5,2 \%$ vs. $5,5 \%$ vs. $4,5 \%$, NS). Zdá se, že tato studie zasadila koncepci facilitované PCI poslední ránu.

Jestliže se facilitovaná PCI při léčbě STEMI neosvědčila, koncepce odstranění trombu $z$ věnčité tepny před implantací stentu se zdá být poměrně účinná. Multicentrická randomizovaná studie zahrnující 1071 pacientů se STEMI zkoumala účinnost manuální aspirační trombektomie ve srovnání s klasickou primární PCI. ${ }^{(6)}$ Ukázalo se, že reperfuze je dokonalejší ve skupině s předchozí provedenou aspirační trombektomií („myocardial blush grade“ 0 nebo 1 u $17,1 \%$ vs. $26,3 \%$ pacientů, $p<0,001)$. Pacienti s horší reperfuzí měli následně vyšší 30denní mortalitu $(p=0,003)$. Je pravděpodobné, že aspirační trombektomie je jednou z mála metod, které jsou schopny optimalizovat výsledek primární PCI u nemocných se STEMI.

Možný nový postup při léčbě STEMI naznačila studie HORIZONS-AMI (Harmonizing Outcomes with Revascularization and Stents in Acute Myocardial Infarction), která zahrnula 3602 pacientů s rozvíjejícím se STEMI do 12 hodin od začátku př́znaků. ${ }^{(7)}$ Pacienti byli léčeni pomocí primární PCI a současně jim byl podán bud' bivalirudin, nebo kombinace heparinu a inhibitoru glykoproteinu
IIb/IIIa. Terapie bivalirudinem vedla $\mathrm{k}$ signifikantně nižší 30denní kardiální mortalitě ( $1,8 \%$ vs. 2,9\%, $p=0,03)$ a rovněž i k nižšímu výskytu úmrtí, reinfarktu, opakované revaskularizace pro ischemii, cévní mozkové příhody a velkého krvácení $(9,2 \%$ vs. $12,1 \%, p=0,005)$. Tato studie znovu doložila vysoké riziko pacientů, u nichž dochází během léčby akutního koronárního syndromu k velkému krvácení. Tudíž, optimalizace farmakoterapie do té míry, aby došlo k významnému ovlivnění intrakoronární trombózy při absenci krvácivé př́hody, je jedním z významných výzkumných úkolů budoucnosti. Studie HORIZONS-AMI naznačila, že přímý inhibitor trombinu bivalirudin může znamenat v této problematice významný posun vpřed.

Jedním z dlouhodobě nejzajímavějších témat intervenční kardiologie jsou biodegradabilní stenty. Jejich koncepce by mohla přinést zajímavý obrat do léčby nemocných s koronární nemocí. Představa implantovaného stentu zabraňujícího stenózám ve věnčitých tepnách, časem se vstřebávajícího a př́padně i potlačujícího rozsah aterosklerotického plátu, je velmi přitažlivá. Zcela recentně byly publikovány výsledky studie $\mathrm{ABSORB},{ }^{(8)}$ která po dva roky sledovala nemocné s implantovaným biodegradabilním stentem vylučujícím everolimus. Na menším vzorku 30 pacientů bylo ukázáno, že klinické výsledky jsou zatím excelentní (pouze jeden pacient utrpěl non-Q-infarkt myokardu během sledování). Stav koronárního řečiště byl monitorován jednak pomocí CT koronarografie, jednak invazivním vyšetřením - intravaskulárním ultrazvukem, optickou koherentní tomografií a angiograficky. Vyšetření ukázala, pouze minimální ztrátu lumina po šesti měsících a následné zmenšení plátu ve sledované oblasti v období mezi 6. měsícem a 2. rokem sledování. Rovněž vstřebání stentů a návrat vasoaktivity v dané oblasti je velmi pozitivní informací. Pokud by tyto nadějné výsledky byly potvrzeny většími studiemi, pak by mohlo dojít po třech desetiletích používání metalických stentů $\mathrm{k}$ zásadním změnám v koronárních intervencích, a to nejen pokud jde o používaný materiál, ale zřejmě i z indikačního hlediska.

Podobně optimisticky vycházejí zatím i postupně publikované výsledky studií s použitím léky potažených balonkových katetrů. Renesance prosté balonkové angioplastiky s lokální aplikací paclitaxelu, který se „obtiskne“ během angioplastiky na intimu intervenované tepny, se zatím týká pouze tepen s menším průměrem, restenóz a pravděpodobně i periferních tepen. Probíhá řada studií, které porovnávají nejen balonkovou angioplastiku s lékovými či klasickými balonkovými katetry, ale srovnávají se i výsledky implantací „holých“ nebo „lékových stentů.“ Zajímavou kombinaci pak představuje aplikace lékového balonku coby nosiče „holého“ stentu. V tomto případě si dovoluji necitovat jedinou studii, ale raději upozorňuji na dva recentně publikované souhrny na toto téma. ${ }^{(9,10)}$

Léčba významných stenóz karotických tepen pomocí implantace stentů (CAS) je jedním $z$ tradičně kontroverzních témat intervenčně zaměřených kongresů. $\mathrm{V}$ loňském roce provedli Theiss a spol. analýzu podskupin registru Pro-CAS, do kterého bylo zahrnuto 5431 pacientů s pro- 
váděnou karotickou intervencí. ${ }^{(11)}$ Nezávislými prediktory nemocničního úmrtí nebo vzniku cévní mozkové př́ihody byly: předchozí symptomy pacienta, věk, množství výkonů prováděných $\mathrm{v}$ daném centru, intervence de novo léze, provedení angioplastiky bez implantace stentu, provedení predilatace a použití vyšší dávky heparinu než 5000 IU. I když se jedná pouze o analýzu rozsáhlého registru, a nikoli o randomizovanou studii, přesto jsou výsledky velmi zajímavé a prrímo aplikovatelné do naší klinické praxe. Hlavním poselstvím studie se zdá být nezbytnost řádného tréninku před započetím programu provádění CAS a správný výběr pacientů vhodných $\mathrm{k}$ této léčbě.

Uplynulo již sedm let od publikace A. Cribiera a spol. ${ }^{(12)}$ týkající se první perkutánní implantace chlopenní protézy do aortální pozice (PAVR). Je podivuhodné, že se během těchto sedmi let nepodařilo dosud publikovat randomizované studie porovnávající PAVR a chirurgickou náhradu. Naštěstí jsou již i tyto studie na cestě a brzy se dozvíme první konkrétní výsledky takového srovnání. Dosavadní zkušenosti týkající se PAVR u vysoce rizikových seniorů jsou poměrně povzbudivé, ačkoli je zřejmé, že první generace perkutánních chlopní má i své nedostatky. Mezi nimi jsou kromě velkého profilu zaváděcího systému i poměrně časté výskyty paravalvulárních regurgitací, především jednorázové uvolnění chlopně bez možnosti následné korekce její polohy. Tyto problémy by do jisté míry mohly řešit další generace perkutánních chlopenních náhrad, které jsou ve fázi implantace reponovatelné, $z$ vnějšku pokryté flexibilní membránou k lepší apozici v oblasti aortálního anulu. ${ }^{(13)}$ Je nepochybné, že dětské nemoci prvních perkutánních systémů budou postupně překonávány a stejně tak se $\mathrm{v}$ rámci tržní kompetice bude postupně snižovat i cena těchto produktů tak, aby je bylo možno běžně používat v naší medicínské praxi. Bude velmi zajímavé sledovat, do jaké míry se perkutánní náhrady uplatní v budoucnu i u pacientů s menším rizikem.

CT angiografie věnčitých tepen (CTA) je jedním z nejvděčnějších výzkumných témat posledního roku. Celá řada studií na toto téma vyšla v prestižních časopisech. Připomínám práci Meijbooma a spol., ${ }^{(14)}$ kteří vyšetřili 360 pacientů se symptomy ischemické choroby srdeční pomocí CTA a nálezy těchto pacientů srovnali s jejich koronarogramy. Tak jako se v posledních letech opakovaně ukázalo, CTA vyniká výbornou negativní prediktivní hodnotou, a tedy i vysokou senzitivitou (97\%, resp. $99 \%)$. Specificita a pozitivní prediktivní hodnota jsou však podstatně nižší (64\%, resp. $86 \%$ ). Stále tedy doporučujeme toto vyšetření nemocným s nižší nebo středně vysokou pravděpodobností ischemické choroby srdeční, s cílem stanovit diagnózu nepřítomnosti koronární nemoci. Do jaké míry ovlivní široké použití CTA náklady na správné stanovení diagnózy významné koronární nemoci, kolika ohroženým nemocným se díky této metodě dostane adekvátní terapie, nebo o kolik se zvýší incidence nádorových onemocnění u vyšetřených pacientů, zůstává zatím nezodpovězeno.

Práce intervenčního kardiologa s sebou nutně přináší rizika, která lékaři museli do jisté míry akceptovat již na počátku své intervenční kariéry. V posledních třiceti letech se celková radiační zátěž intervenčních kardiologů podstatně zvýšila. Bezprostřední důsledky chronické radiační zátěže nepocitujeme již dnes proto, že střední generace intervenčních kardiologů, která byla v ČR motorem dynamického růstu výkonů v letech 1995-2005, ještě nekatetrizuje „dostatečně dlouho, aby na sobě důsledky radiace pocitovala“. Na toto téma bylo v posledních letech publikováno mnoho prací, nicméně všem čtenářům mohu doporučit článek Kleina a spol., ${ }^{(15)}$ kteří formulovali rizika dlouhodobé práce $\mathrm{v}$ katetrizační laboratoři. Autoři jsou přesvědčeni, že neexistuje nízká a tolerovatelná dávka záření, ale každá dávka má své biologické konsekvence včetně růstu rizika onkologických onemocnění (zvláště tumorů mozku), hematoonkologických onemocnění a rovněž katarakty. Kromě záření přináší dlouhodobá statická práce $\mathrm{v}$ olověné zástěře svá rizika týkající se pohybového aparátu. Téměř polovina vyšetřovaných amerických lékařu uvádí chronické bolesti zad, což je dvojnásobné množství než zbytek populace. Je nezbytné, abychom své ochraně věnovali do budoucna mnohem více pozornosti, protože za dalších 10-20 let práce $\mathrm{v}$ katetrizační laboratoři již může být pozdě.

\section{Literatura}

1. Tonino PA, DeBruyne P, Pijls N, et al. Fractional flow reserve versus angiography for guiding percutaneous coronary intervention. N Engl J Med 2009; 360:292-4.

2. Serruys PW, Morice MC, Kappetein P, et al. Percutaneous coronary intervention versus coronary-artery bypass rafting for severe coronary artery disease. N Engl J Med 2009;360:961-72.

3. Boden WE, O'Rourke RA, Teo KK, et al. Optimal medical therapy with or without PCI for stable coronary disease. N Engl J Med 2007;356:1503-16.

4. Weintraub WS, Spertus JA, Kolm $\mathrm{P}$, et al. Effect of $\mathrm{PCl}$ on quality of life in patients with stable coronary disease. N Engl J Med 2008;359:677-87.

5. Ellis SG, Tendera M, de Belder MA, et al. Facilitated $P C I$ in patients with ST- elevation myocardial infarction. N Engl J Med 2008;358:2205-17.

6. Svilaas T, Vlaar PJ, van der Horst IC, et al. Thrombus aspiration during primary percutaneous coronary intervention. N Engl J Med 2008;358:557-67.

7. Stone GW, Witzenbichler B, Guagliumi G, et al. Bivalirudin during primary $\mathrm{PCl}$ in acute myocardial infarction. N Engl J Med 2008;358:2218-30.

8. Serruys PW, Ormiston JA, Onuma Y, et al. A bioabsorbable everolimus-eluting coronary stent system (ABSORB): 2-year outcomes and results from multiple imaging methods. Lancet 2009;373:897-910.

9. De Labriolle A, Pakala R, Bonello L, Lemesle G, Scheinowitz M, Waksman R. Paclitaxel-eluting balkon: From bench to bed. Catheter Cardiovasc Interv 2009;73:643-52.

10. Scheller B, Speck U. Potential solution to the current problem: coated balloon. Eurolnterv 2008; Suppl C:C63-C6.

11. Theiss W, Hermanek $P$, Mathias $K$, et al. Predictors of death and stroke after carotid angioplasty and stenting. A subgroup analysis of the Pro-CAS Data. Stroke 2008:39:2325-30.

12. Cribier A, Eltchaninoff $H$, Bash $A$, et al. Percutaneous transcatheter implantation of an aortic valve prosthesis for calcific aortic stenosis: First human case description. Circulation 2002;106:3006-8.

13. Buellesfeld L, Gerckens U, Grube E. Percutaneous implantation of the first repositionable aortic valve prosthesis in a patient with severe aortic stenosis. Catheter Cardiovasc Interv 2008;71:579-84.

14. Meijboom WB, Meijs MFL, Schuijf JD, et al. Diagnostic accuracy of 64-slice computed tomography coronary angiogramy: a prospective, multicenter, multivendor study. J Am Coll Cardiol 2008;52:2135-44.

15. Klein LW, Miller DL, Balter S, et al. Occupational health hazards in the interventional laboratory: time for a safer environment. Catheter Cardiovasc Interv 2009;73:432-8. 